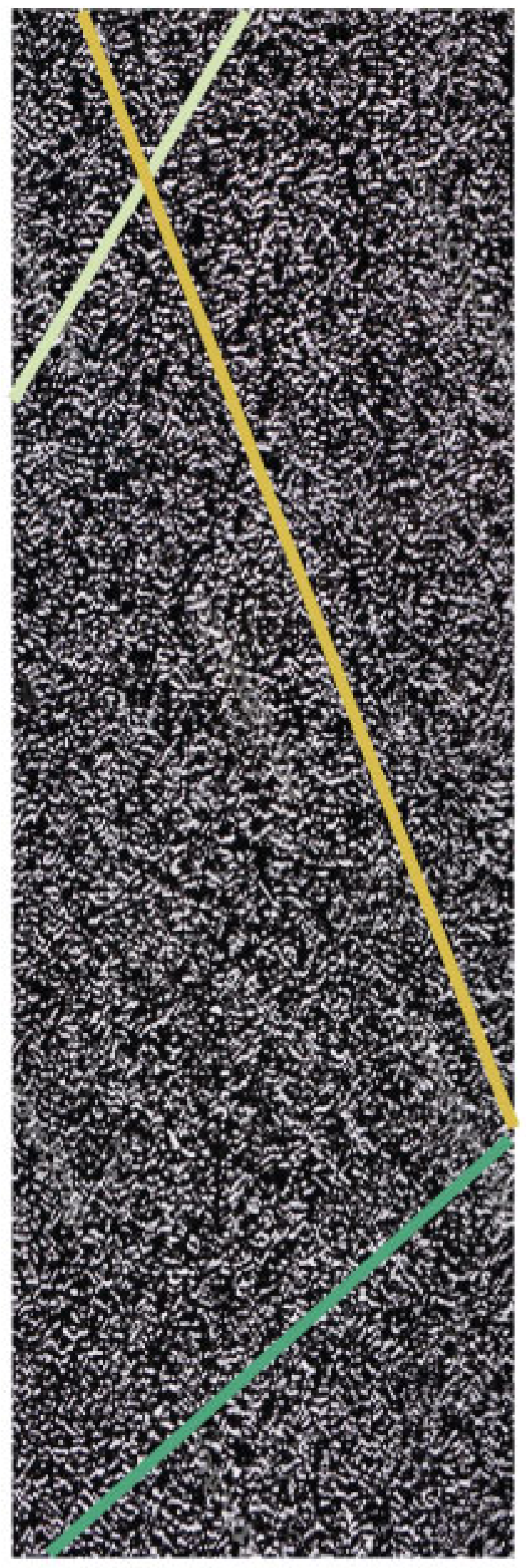

\section{G) Dominios}

FACES EXPRESSIVAS DE UMA EXPERIENCIA COLETIVA: ARTES PLÁSTICAS E CINEMA EM BELÉM NOS ANOS 1960

\author{
EXPRESSIVE FACES OF A \\ COLLECTIVE EXPERIENCE: PLASTIC \\ ARTS AND CINEMA IN BELÉM IN THE \\ 19605
}

Cleodir Moraes'
1 Doutor em Historio pelo Universidoda Federd de Uberlandia [UFU/MG]. Professor da Escola de Aplicaçóo do Universidade Federal do Pará [EAUFPA] e do Programa de Mestrado Profissional em Ersino de Histótia |Prollestória), da mesma instituleoo, compus Anonindeva. E-mal: clecodrmoraes Buolcom.br. 


\section{Resumo}

As experimentações artísticas verificadasemBelém, nosanos 1960, fornecem indícios de inquietações e propostas de renovação. Embora não constituíssem um corpus homogêneo em termos temáticos, procedimentais e materiais, elas deixaram transparecer traços em comum. Um dos mais evidente foi conceberem a cidade, espaço de transformações e contradições, como palco, mote e personagem. Em sintonia com essa perspectiva, estavam a mostra de jovens artistas plásticos, autodenominados "Grupo" (1966), e as realizações cinematográficas

Brinquedo Perdido (1962), Vila da Barca (1965), Um dia qualquer (1965) e Belém 350 anos (1966). A partir das contribuições de WILLIAMS (1979), KOSELLECK (2006), entre outros, este artigo visa abordar aspectos socioculturais e estéticos dessas obras, que ajudam a refletir sobre as diferentes maneiras de perceber, ser e viver nesse espaço urbano.

Palavras-chave: História; Artes Keywords: History; Plastic Arts; Plásticas; Cinema; Belém.
Abstract

The artistic experiments that were verified on Belém, in 1960s, provide indication of unrest and renovation proposals. Although they did not constitute a corpus that is thematically, procedurally and materially homogeneous, they did show some traces in common. One of the most evident traces was conceiving the city, a place of transformation and contradiction, as a stage, motivation and character of its creations. In line with this perspective was an exhibition by a crew of Young plastic artists, self-denominated "Grupo", as were the cinematic achievements Brinquedo Perdido (1962), Vila da Barca (1965), Um dia qualquer (1965) and Belém 350 anos (1966). From the contributions of WILLIAMS (1979), KOSELLECK (2006), among others, this article seeks to address the sociocultural and aesthetic aspects of these works of art, which then help us to reflect on the different ways of percieving, being and living in this urban space.
Cinema; Belém. 


\section{Introdução}

Nos anos 1960, estava em curso um processo de reconfiguração do fazer artístico em Belém. As experimentações verificadas nos diferentes campos - musical, poético, teatral, cinematográfica e pictórico - fornecem indícios das inquietações que agitaram - mundo das artes na capital paraense. Embora as propostas não constituíssem um corpus homogêneo em termos temáticos, procedimentais e materiais, elas deixaram transparecer traços em comum. Entre eles, um dos mais evidentes foi o fato de terem capturado a cidade, espaço de contrastes e em constante movimento, como cenário, mote ou personagem.

A dinâmica das mudanças na fisionomia física da cidade e suas implicações sociais e culturais, de uma forma ou de outra, concorreram para esse proceder. Os melhoramentos então realizados, como a abertura, ampliação e pavimentação asfáltica de vias, iluminação pública, reforma de praças, construção de novos prédios residenciais, institucionais e comerciais e de suntuosos "arranha-céus", trouxeram ânimo novo à parcela significativa de seus moradores, ao mesmo tempo em que acentuaram contradições. Soma-se a isso, as expectativas de desenvolvimento geradas pelo asfaltamento da rodovia BelémBrasília e pelos planos federais de integração e colonização da região (PENTEADO, 1968; CHAVES, 2008, 2011).

Para além dos efusivos discursos oficiais, questões relativas a esse processo também vieram à tona de maneira peculiar, por meio da sensibilidade de grande parte da classe artística, a exemplo de pintores e cineastas. Daí porque este artigo se debruçar sobre aspectos estéticos e socioculturais evidenciados em algumas realizações cinematográficas e no campo das artes plásticas. A partir do cruzamento de suas concepções formais - quando possível - e discursivas com outras fontes imagéticas, escritas e orais, busquei investigar os rastros de atribuição de sentido ao vivido, que conferem expressividade às obras (WILLIAMS, 1979, p. 134). O exame 
dessas experiências históricas ajuda a refletir sobre formas de perceber, ser e viver nesse espaço urbano, subjacentes a certa consciência prática do presente, articulada ao conhecimento e interpretação do passado e às expectativas de futuro projetadas pelos sujeitos envolvidos (KOSELLEK, 2006, p. 304-327).

Essas vivências mais imediatas, mais rés ao chão, mas não presas ou restritas a ele, dialogavam, de modo específico, com as pulsões do tempo, no qual elas foram realizadas. Isso significa dizer que os embates em torna de soluções estéticas no Brasil, que colocavam em questão o papel e a função da arte na sociedade e mobilizavam intrincadas interação de pares explicativos antitéticos, como tradicional/moderno, regional/nacional, nacional/ universal, não passaram ao largo das preocupações dos produtores culturais em Belém. Como se verá, a relativa sincrônica com que os fenômenos artísticos se constituíram nesse período, assume sentido histórico se levarmos em conta o tempo e lugar em que essas mudanças interpretativas e formais aconteceram.

\section{Em busca de um novo figurativismo nas artes plásticas}

O jornal A Província do Pará, em dezembro de 1966, noticiou a realização de uma mostra coletiva ocorrida entre os dias 22 e 30 do mês anterior. O colunista Flávio Marajó (1966, p. 1), ao assinar a matéria sob o título a "Jovem arte", seguido do subtítulo "ou a revolução do Grupo", não conseguia esconder a alegria diante do que vira. Tanto que procurou não só relatar em detalhes, como observadoratento, suas impressões sobre alguns quadros, como, ainda, descreveu comentários dos próprios artistas a respeito deles.

Parte dessa euforia se deveu ao fato de o "Grupo" ser formado por figuras jovens, com, em média, 25 anos, e conhecidas do colunista e na cena local. Dele participavam o escritor Fernando Lúcio Martins, a poetisa Annamaria Barbosa Rodrigues, o jornalista e poeta José Arthur Bogéa, o professor, ator e restaurador, João Cesar Mercês e o aplaudido ator e cantor Walter Bandeira, que também exercia o cargo de professor da Escola de Teatro da Universidade Federal do 
A galeria recebeu esse nome em homenagem a Ângelus Nascimento pseudônimo do desenhista e caricaturista maranhense radicado em Belém, Antônio Ângelo de Abreu Nascimento, falecido em 1959.

${ }^{2}$ Intelectuais, empresários e artistas não só aplaudiram a ideia como também, empenharam tempo e dinheiro na sua concretização. Entre eles estavam o arquiteto Donato Mello Júnior professor da faculdade de Arquitetura, Adriano Menezes, diretor do Banco do Estado do Pará, os pintores Benedicto Mello e Ruy Meira, o poeta José Sampaio de Campos Ribeiro e o crítico Francisco Paulo Mendes.
Pará (UFPA). Foi a primeira vez - e seria a última - que a maioria deles apresentou suas experimentações pictóricas para além dos circuitos familiares e de amizade. Antes disso, apenas Fernando Martins e Arthur Bogéa tiveramoportunidade de exibir seus quadros para um público mais amplo e diversificado, quando participaram do II Salão de Artes Plásticas da UFPA, no anto anterior.

É preciso destacar, ainda, a importância histórica e cultural do lugar onde ocorreu a exposição: a Galeria Ângelus . ' Inaugurada, em 21 de outubro de 1966, no foyer do tradicional e luxuoso Teatro da Paz, ela se constituiu no primeiro espaço público destinado exclusivamente às artes plásticas da cidade, já que anteriormente os salões eram acomodados em residências particulares, em clubes sociais ou nas dependências da Biblioteca e Arquivo Público do Pará(GODINHO, 1986a, p. 7). A iniciativa partiu do maestro Waldemar Henrique, que, à época, acumulava as funções de diretor do Teatro e símbolos da cultura erudita do Departamento de Cultura da paraense. Antes deles, apenas Secretaria de Educação e Cultura João Pinto Martins e Concy do Estado (DC/Sedec), logo após ele ter retornado, em abril de 1966, de uma temporada de 30 anos residindo no Rio de Janeiro. ${ }^{2}$

Concluídos os trabalhos de adaptação, as atividades da galeria foram abertas com a apresentação de 30 telas a óleo de Concy Cutrim e 20 esculturas de João Pinto Martins. O episódio, seguindo a ritualística tradicional dos eventos dessa natureza em Belém (SOBRAL, 2002, p. 56), converteu-se em grande acontecimento social, contando com a presença de pessoas de destaque no "mundo intelectual" da sociedade local, convidados e personalidades políticas, como o prefeito Stélio Maroja (GODINHO, 1986a, p. 7).

A mostra protagonizada pelos integrantes do Grupo ganhou, assim, ares de ousadia - ou, para o articulista, "revolucionários" -, ao trazer a público criações inovadoras, nada mais, nada menos, do que em um salão pomposamente recéminaugurado, dentro de um dos João Pinto Matins e Concy 
Cotrim e o pintor amazonense Moacir Couto de Andrade tinham passado por ali. Além do mais, logo em seguida, ele receberia quadros de Agi Straus, pintora austríaca, radicada em São Paulo, reconhecida no cenário nacional e internacional (GODINHO, 1986b, p. 3).

Houve, por esses motivos, grande expectativa quanto à receptividade das obras. Afina elas apontavam, em linhas gerais, paraescolhas discursivase estéticas distintas daquelas adotadas pelos que os precederam e por outros considerados mais representativos das artes plásticas paraense, como José Pires de Moraes Rego, Dionorte Drummond Nogueira, Paolo Ricci, Benedicto Mello e Ruy Meira.

Esses artistas eram vistos como responsáveis pela quebra de alguns cânones acadêmicos, ao insurgirem-se contra o figurativismo mimético, devotado à reprodução do visível - natureza, indivíduos e paisagens -, embora quase todos eles já tivessem passado por essa "fase" em suas trajetórias artísticas. ${ }^{3}$ $\mathrm{Na}$ opinião do crítico Francisco Paulo Mendes (apud SOBRAL, 2002, p. 74-75), eles tiveram importância significativa ao demostrarem a vitalidade criativa da arte moderna em Belém diante das velhas convenções academicistas "impostas em nome da 'sagrada arte', da 'beleza imortal', da 'imitação da natureza' e de todas as outras fórmulas da paralisia intelectual, da atrofia estética e de consagração de tolices e de inércia provinciana".

Reunidos em grupos, como - Clube de Artes Plásticas da Amazônia-Capa (1959) e o Gestalt (1960), eles buscaram em suas composições o equilíbrio cromático, em variadas formas, gestos e luminosidade, sensíveis à estética abstracionista. ${ }^{4}$ Contribuíram, assim, para inserir, mesmo tardiamente, a produção local nos debates, em voga nos anos 1950, em torno do estatuto e da função da arte no Brasil e o ingresso do país no concerto das nações, no contexto pós-Segunda Guerra Mundial (NAVES, 2003, p. 297; COUTO, 2004, p. 78).

Quando O Grupo expôs na galeria Ângelus, em 1966, os quadros de feições abstracionistas ainda eram os preferidos da crítica.
3 Isso não significou, no entanto, a ruptura completa e definitiva com as vanguardas nacionais e internacionais de tendências surrealistas, impressionistas e pósimpressionistas, por entre as quais eles se movimentaram, no final da década de 1940 e nos anos 1950, com certa desenvoltura.

4 Ressalte-se, entre os nomes já citados, a importância de Estela Campos nesse cenário, figura invisibilizada pela historiografia e pala memória histórica construída a respeito da introdução e produção da estética abstracionista em Belém (COSTA, 2018, p. 704-705). 
Penso que as pressões e limitações políticas e culturais vivenciadas no imediato pós-golpe de 1964, que tomara de assalto o país, não podem ser ignoradas ou minimizadas nos estudos das obras produzidas dentro dessa nova conjuntura, especialmente aquelas que apontam para certa perspectiva de inserção social, como no caso em questão, mesmo considerando que elas também tenham se manifestado diante da "sociedade urbanoindustrial" do período, em uma região "longínqua e pouco industrializada", como sugere Gil Vieira Costa (2019, p. 267).
As mostras individuais e coletivas realizadas entre 1959 e 1963 e as premiações conquistadas nos salões da Universidade Federal do Pará, nos anos de 1963 e 1965, dão provas desse reconhecimento.

No contrafluxo desse ideal, 2013).

os participantes do Grupo procuraram exprimir suas sensibilidades, conectadas, de um lado, a questões sociais resultantes do processo de desenvolvimento urbano em curso desde, pelo menos, o início da década, e, de outro, às mudanças repentinas na conjuntura política e cultural brasileira, no pós-golpe civil-militar de $1964 .^{5}$

Com isso, pretendiam fazer a crítica da "arte pela arte", ao subjetivismo exacerbado e empenhado na busca de certa pureza pictórica, fundada em traços e cores, caros às tendências abstracionistas - informalistas, tachistas, construtivistas -, que predominavam em Belém. João Mercês lembra que ele e os demais "não se misturavam" com aqueles sujeitos, então, mais badalados e pouco se identificavam com o que eles faziam em termos artísticos (MERCÊS, 2013). Também estavam nenhum pouco interessados em proporem um retorno à figuração de décadas passadas, a qual Ihes parecia "muito clássica" e dedicada a reproduzir natureza, pessoas e comunidades (MERCÊS,

A julgar por esse depoimento e pelosrelatosdaépoca,João Mercês e os demais expositores estavam dispostos a exibir uma arte que se pretendia inovadora, focada no homem brasileiro e afinada, mesmo que tangencialmente, com o novo figurativismo, defendido por parte vanguardas nacionais. Tencionavam, ainda, empreenderem ações de educação das "massas", no ano seguinte, por meio da realização de apresentações volantes nos bairros mais populosos de Belém, como Pedreira, Condor e Marambaia (MARAJÓ, 1966, P. 1) projeto este que, no entanto, não saiu do papel, em razão do tempo que dispunham e da priorização de outras atividades artísticas e profissionais.

O desejo de "ida ao povo" não passou despercebido aos olhos do colunista. Ele notou que essa "preocupação social" poderia ser 
percebida nos títulos dos quadros, a exemplo de Reconhecimento da angústia, Janela da alma, O homem e sua hora, Os sós e Nu-ânsias. A retomada do figurativismo nas artes brasileiras tinha algo a ver com essa inquietação e a necessidade de incorporar ingredientes sociais, como garantia de legitimidade e autenticidade da obra.

Nesse diapasão,

O experimentalismo que caracterizou as vanguardas brasileiras, na década de 1960, abriu caminho ao surgimento de propostas de caráter engajado e participante, na busca de liberdade criativa. No campo das artes plásticas, verificou-se 0 progressivo enfraquecimento do abstracionismo, a retomada da figuração de caráter alusivo e as primeiras incursões no sentido de integração da cultura de massa. Na procura da eficácia comunicacional, muitos artistas se mostraram sensíveis aos fenômenos urbanos e suas implicações socioculturais, ao avanço dos meios de comunicação e aos temas populares (COUTO, 2004, p. 200).
Essa tendência foi, igualmente, a tônica dos trabalhos dos integrantes do Grupo, sem que, com isso, optassem pela feitura de uma arte up to date, como Ferreira Gullar se refere às tentativas de atualização pura e simples em relação às vanguardas internacionais (GULLAR, 1969, p. 68). Como frisou João Cesar Mercês,

\begin{abstract}
O que nós fizemos, nada parecia com o que já se tinha feito (...) todo mundo [era] universitário, com outro tipo de leitura, que, embora trabalhando com a questão local, com a questão daquilo que acontece num determinado espaço [Belém] (...) acaba entrando numa linguagem universal, porque quando você faz uma coisa daqui mesmo, muito regional, você não abre para uma outra coisa, fica aqui, fica preso aqui, fica amarrado aqui (MERCÊS, 2013).
\end{abstract}

Ele levanta, contemporaneamente, uma questão de fundo que orientou os debates e propostas de soluções estéticas nos diferentes campos artísticos na capital paraense, nos anos 1960: os embates entre o regional, o nacional e o universal. Esse tema estava - e ainda, de certa forma, está - associada às relações de 
Exemplo significativo da permanecia desse entendimento é a conclusão a que chegou Acácio Sobral no seu estudo sobre arte abstrata em Belém: "o interesse pelo abstracionismo no Pará (1959 a 1963) desenvolvido por um grupo de artistas desencadeou 0 fim do isolamento cultural vivido pela cidade" até aquele momento (SOBRAL, 2002, p. 89). poder simbólico e material que estabeleceram como dadas as distintas camadas com as quais a memória histórica convencionou interpretar e hierarquizar as condições sociais e culturais do país, comparando as diferentes regiões brasileiras, a partir da lógica do atraso e do isolamento. ${ }^{6}$

Esse esquema compreensivo da produção e circulação cultural, que, nos mais das vezes, limitou-se às divisões político-administrativas e às concepções civilizatórias e de desenvolvimento material que acompanharam $\bigcirc$ processo de ocupação do território brasileiro, orientaram os olhares de muitos artistas e críticos no período. Reproduziu-se, aqui e em outras cidades, uma espécie de razão dualista, sobre a qual, por muito tempo, se ancorou grande parte do pensamento social brasileiro (OLIVEIRA, 1972, p. 3-82), cujo exemplo mais bem acabado pode ser encontrado na noção de "dois Brasis", do sociólogo Jacques Lambert (1969, p. 101-128).

As obras da mostra realizada pelo Grupo ao dialogarem com algumas experimentações plásticas desenvolvidas pelas vanguardas nacionais, o fizeram a partir de referências e materiais ligados às experiências históricas de seus produtores. Isso porque, as notícias fragmentadas que aqui chegavam sobre os embates estéticosnacionais einternacionais, embora filtradas pelos comentários de críticos, colunistas, amigos e meios de comunicação, tiveram alguma ressonância entre esses eles, quando mais não seja, porque já faziam uso de determinados ingredientes criativos evidenciados nesses debates, a ponto de os levarem a sério.

Walter Bandeira, por exemplo, apresentou dois quadros nãofigurativos, resultados de suas incursões pela "pintura lisa, em dois planos", utilizando a técnica de colagem. Ele admitiu, na oportunidade, ter pouco conhecimentodoneofigurativismo, referindo-se, provavelmente, às tendências e discussões nesse campo, acentuadas em São Paulo e no Rio de Janeiro, desde o início dos anos 1960. Isso não quer dizer, em absoluto, que a figuração de caráter alusivo não fizesse parte de suas criações. É possível flagrar que uma de suas aquarelas (Imagem 1) 
- técnica mais usada por ele e da qual se tem mais conhecimento ${ }^{7}$

- fazia eco, por outras vias, submersa naquele ambiente. à proposta de arte social e A tela foi feita, como tantas humanizada do Grupo.

Imagem 1 - Sem Título, guache s/ papel, 1966.

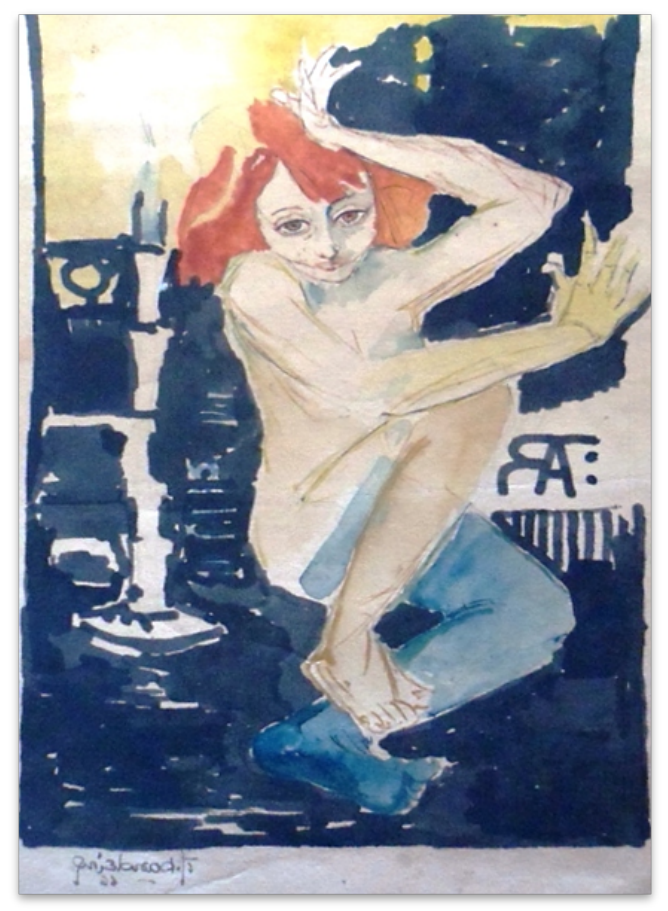

Fonte: Acervo pessoal, Simone Bandeira Gonçalves.

Na obra, datada de 1966, a disposição pictórica, à base de cores primárias, dimensiona a relação luz e sombra de tal forma que a escuridão toma conta de quase toda espacialização do papel, arrebatada apenas por um misto de luminosidade natural e artificial, a destacar o corpo nu e solitário de mulher, em pose sensual, outras, nos instantes de "fuga" de Walter Bandeira. Momentos "só dele", de recolhimento ao "ateliê" improvisado em sua casa, acompanhado pelo "papel, o pincel e as cores" (GONÇAVES, 2013), de onde brotaram formas distorcidas, em modulações cromáticas, abertas, em muitos casos, ao sensual, ao feminino, à solidão e ao urbano.

Essa sensibilidade adquire força expressiva e significação histórica se conflitada com a rotina diária, corrida e movimentada, desse cantor, ator e professor. A fuga se manifesta como resposta a um tempo de transformações socioculturais, tal qual sentidas por ele, principalmente se levarmos em conta sua presença marcante na cena musical da cada vez mais agitada vida noturna de Belém, no processo de formação e consolidação da música popular brasileira, sob a sigla MPB, na cidade (MORAES, 2014, p. 70-71).

Diferentemente de Walter Bandeira, João Mercês foi um
7 Entre os dias 23 de agosto a 29 de setembro de 2016 . - salão Museu da UFPA abriu suas portas abertas à apreciação pública da exposição "Walter Bandeira - o canto das aquarelas", contendo 60 telas das mais de cem aquarelas do artista, falecido em 2009. 
dos poucos a se aproximar mais diretamente das experiências artísticas das vanguardas nacionais, quando frequentava, havia três anos, o curso de restauro e conservação na Escola Nacional de Belas Artes (ENBA), no Rio de Janeiro, com bolsa de estudo concedida pela UFPA. Isso aconteceu quase no mesmo período em que Asreia El-Jaick cursara desenho e pintura na ENBA e Vilma Pasqualini expusera na mostra Opinião 65, no Museu de Arte Moderna. Vem daí, provavelmente, a relação que fez Flávio Marajó entre as propostas neofigurativistas exibidos por João Mercês na Galeria Ângelus e as obras dessas duas artistas.

Vale dizer que a ideia básica dos participantes da Opinião 65, à semelhança do espetáculo Opinião do ano anterior, era, como o nome sugere, manifestarse diante da nova realidade sociocultural e política do país, aliando $\bigcirc$ experimentalismo estético à necessidade de exprimir uma percepção crítica do momento (REIS, 2005, p. 8293). Os trabalhos aí apresentados e a repercussão que eles tiveram abriram, sem dúvida alguma, um leque de possibilidades plásticas, que, grosso modo, caminharam em direção a uma nova figuração, alinhadas, em grande medida, às contribuições concretistas e neoconcretistas dos anos anteriores. Essa preocupação de opinar sobre a realidade social, indicava uma atitude crítica diante dos cerceamentos impostos às liberdades individuais e coletivas, às condições de vivência na sociedade urbanoindustrial, o subdesenvolvimento do país, às tentativas de absorção da pop art e à tomada de posição frente a sociedade de massas, problemáticas que serão retomadas pelo movimento tropicalista, em suas variadas manifestações, no final da década. A maioria dos quadros expostos pelo Grupo se inscreveram nessa perspectiva interpretativa. Em termos discursivos, eles foram tomados como representantes da "arte jovem" de Belém, que avançava "em ousadia e novos caminhos", a partir da realidade local (MARAJÓ, 1966, p. 1). Arthur Bogéa, por sua vez, avaliou que suas pinturas se revestiam de uma 
dimensão humana fundamental, impõe limites ao exame direto e, ao abordarem o "tédio do em tese, mais preciso. Em todo burguês-só-burguês", como em caso, é possível perceber alguns Prelúdio, Exaustão e Nu, ou a traços importantes para este "miséria do povo-só-povo", em estudo, nos relatos sobre eles.

Lavadeira e Pescador. Para João Cesar Mercês, cujos quadros foram considerados os mais bonitos e significativos ali exibidos, suas obras tinham a preocupação de tematizar "o homem da nossa época, principalmente $\mathrm{o}$ das grandes cidades", assim como "a influência da máquina na conduta das pessoas, o salvar-se por si e o ser só entre a multidão" (MARAJÓ, 1966, p 1).

A angústia e a solidão humanas, entendidas como resultados dramáticos das pressões sentidas de viver em lugares desenvolvidos e em desenvolvimento, à semelhança do que se observa na aquarela de Walter Bandeira, foram temas centrais nas telas de Annamaria Barbosa Rodrigues. Ela entendia suas pinturas como expressões pictóricas de suas poesias, nas quais solidão, homem, da sociedade em que amargura, "a noite mais noturna", vivem"' (GULLAR apud COUTO, também eram referências constantes.

Com base nessas informações, pode-se dizer que a mostra não apresentou homogeneidade formal ou temática, sendo as pinturas concebidos a partir de técnicas variadas, que, a despeito do compromisso estético com a inovação, transitaram entre o nãofigurativo e o novo figurativismo, com o uso de materiais e suportes distintos. A tônica foi experimentar novas possibilidades plásticas com objetos e referências conectadas ao cotidiano urbano. Eles demonstraram, dessa maneira, respirar, por assim dizer, os ares de renovação que também oxigenavam as artes plásticas em outras capitais do país, cujas pretensões sociais reverberavam em uma "nova arte humanista, 'plena de interesses pelas coisas do mundo, pelos problemas do 2004, p. 207).

A partir da incorporação

Os trabalhos do Grupo se de materiais diversos em seu perderam com o tempo, o que labor artístico, os membros do 
Grupo questionaram os suportes tradicionais e o próprio estatuto da obra de arte, ao promoverem a interação estética entre diferentes linguagens, como pintura, escultura e poesia. Os quadros de João Cesar Mercês, que ostentaram melhor domínio técnico, eram compostos de "figuras talhadas em madeira, cera, vinil e pigmento puro usado com a ajuda de um maçarico" (MARAJÓ, 1966, p. 1). Em O homem e sua hora, uma homenagem ao poema homônimo de Mário Faustino, falecido em 1962, e considerado o melhor realização de Arthur Bogéa, este explorou a plasticidade de elementos em "madeira, cobre, arame, tubo plástico, uma corrente de bicicleta, um relógio, além de outros objetos de ferro", na criação de figuraras projetadas em uma superfície plana (MARAJÓ, 1966, p. 1). Pintura e escultura se conjugavam, assim, para garantir a expressividade desejada.

Aliás, a proposta de "pinturasesculturas" apresentada nos quadros de Arthur Bogéa dialoga com seus "desenhos-esculturas", publicados, à época, no caderno de cultura do jornal A Província do Pará (Imagens 2, 3, 4 e 5).
Imagem 2 - Ilustração, s/título.

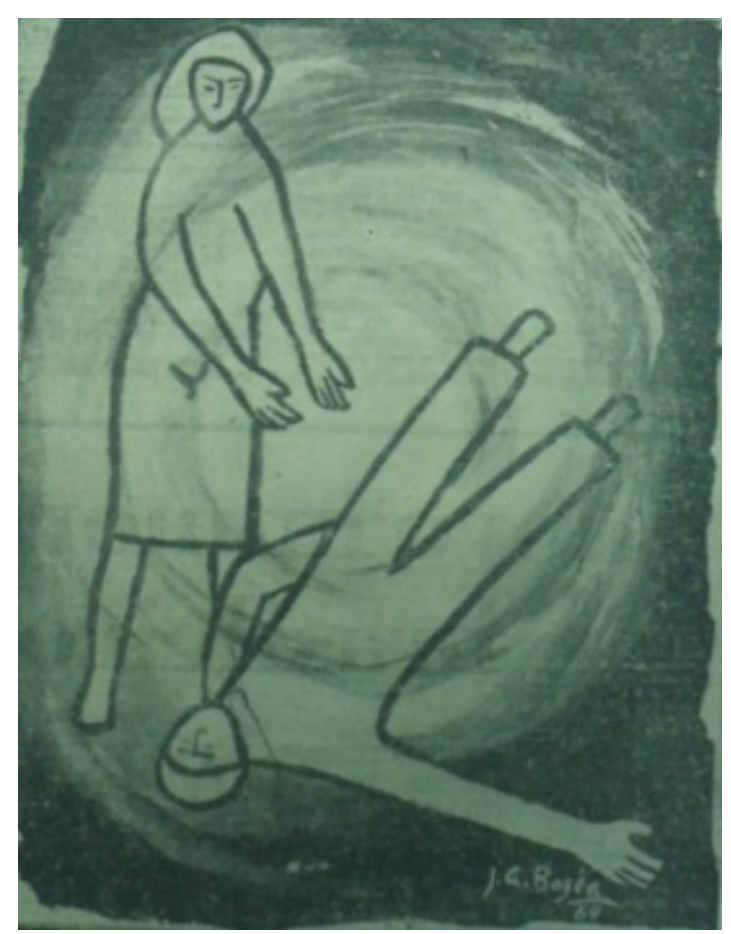

Fonte: A Província do Pará, 10 maio 1964, 3. cad., p. 1.

Imagem 3 - llustração, s/título.

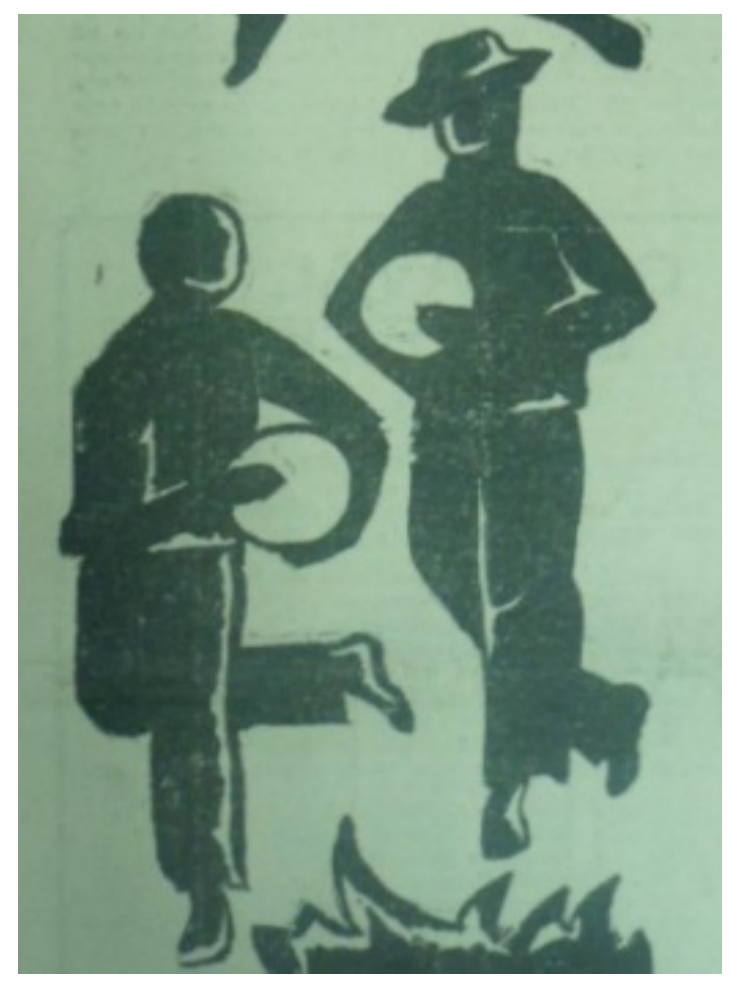

Fonte: A Província do Pará, 9 fev. 1964, 2. cad., p. 1. 
Imagem 4 - llustração, s/título.

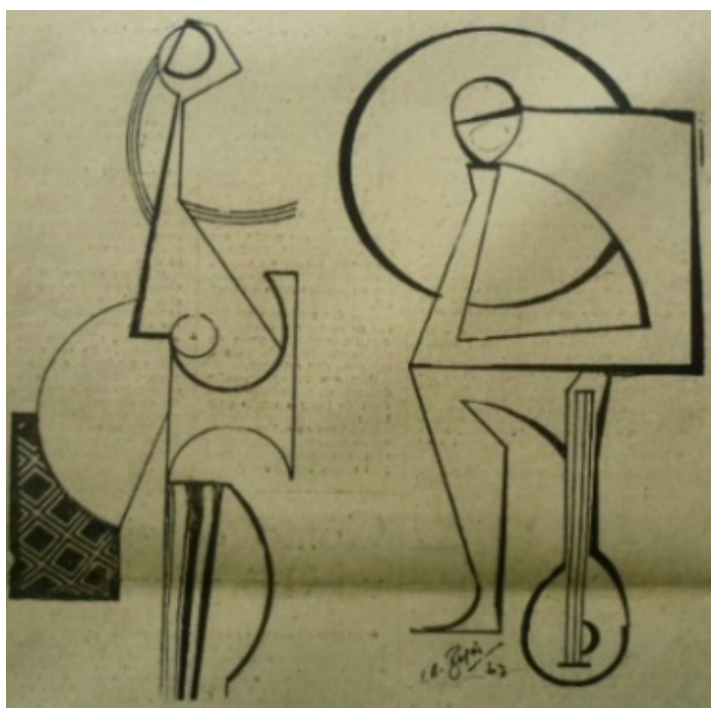

Imagem 5 - llustração, s/título.'

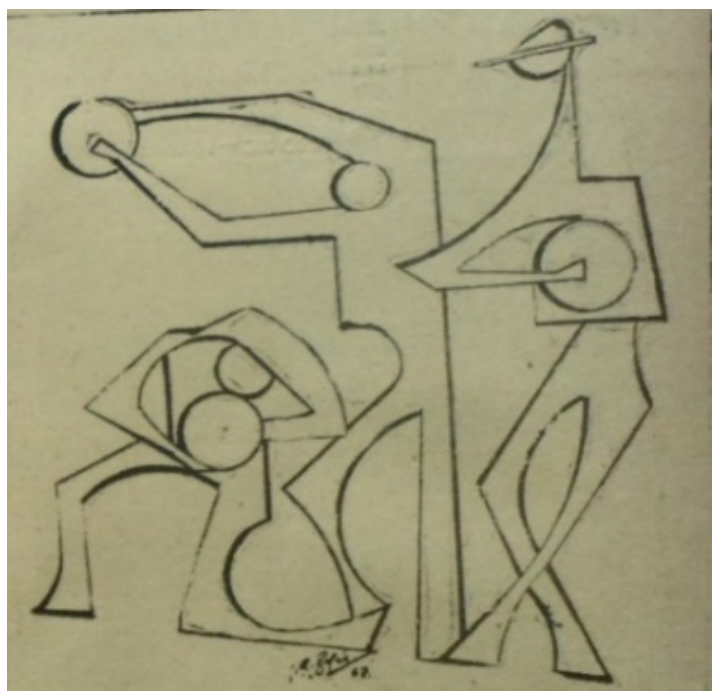

Fonte: A Província do Pará, 5 fev. 1967, 3. cad., p. 1 e 2.

Esses desenhos, que, em formal relativamente a uma das geral, serviam de projeção tendências de renovação das imagética para poemas, contos artes plásticas brasileiras, qual seja, e resenhas divulgados naquele a integração estética de diferentes caderno, fornecem indícios da linguagens nas experimentações movimentaçãodoartistanocampo imagéticas e sensoriais do período figurativo. As ilustrações de 1964, (COUTO, 2004, p. 100-114). diferem bastante daquelas registradas três anos depois. Estas revelam imagens estilizadas em composições simétricas, a descortinarem silhuetas de figuras esguias, traçadas no papel, em planos geométricos e vasados, que se aproximam, sobremaneira, de esculturas do paulista Bruno Giorgi, como Os Guerreiros (ou Os Candangos), de 1960, construída para ornamentar a Praça dos Três Poderes, em Brasília. ${ }^{8}$ Vale dizer que as fontes disponíveis não permitem sugerir qualquer "influência" direta dessa obra nas ilustrações de Arthur Bogéa. Tampouco é o objetivo desse exercício do olhar. Trata-se de uma comparação livre, que serve, tão-somente, para evidenciar, extensão, nas pinturas-esculturas do pintor paraense, a sua afinidade
Agradeço ao amigo, historiador Silvio Ferreira Rodrigues, por essa oportuna contribuição. 
Nascido em Belém, em 1943, Renato Tapajós mudouse, aos 19 anos, para São Paulo com objetivo de estudar Engenharia na Escola Politécnica. Ele aabandonou o curso pouco tempo depois e foi cursar Ciências Sociais, na USP, que também não concluiu devido, entre outras coisas, a sua militância no movimento estudantil. Filiouse ao Partido Comunista do Brasil (PC do B) e aí ajudou a fundar o grupo dissidente Ala Vermelha, partidário da uta armada. Foi preso em 1969 e solto 1974. Na prisão ele começou a escrever "Em câmara lenta", publicado em 1977, que lhe rendeu novo processo e prisão, por tocar em questões polêmicas, como guerrilhas e torturas. Além de Vila da Barca, produziu outros documentários, a exemplo de Universidade em crise (1966), Greve de março (1979), Luta do povo (1980) e Nada será como antes (1985).
Em 1966, alguns comentários críticos foram esboçados em relação aos trabalhos expostas pelo Grupo. Francisco Paulo Mendes, Paulo Penna Firme e Sara Feres disseram-se "entusiasmados" com o que viram (MARAJÓ, 1966, p. 1). Isso não foi o suficiente para que a mostra tivesse alcançado outra fortuna, que não a quase total invisibilidade nas pesquisas sobre a história da arte em Belém.

Olhares cruzados: a cidade em transe na tela do cinema

Atitudes renovadoras

alcançaram, igualmente, a produção cinematográfica.

Cineastas de diferentes pontos do Brasil se mobilizaram para atestar seu engajamento no trato de questões socioculturais e políticas em meados da década de 1960. Em Belém, Renato Tapajós ${ }^{9}$ procurou imprimir uma feição crítica ao documentário Vila da Barca (TAPAJÓs, 1965), premiado no festival de Leipzig, na Alemanha, em 1968.

As filmagens começaram no final de 1964, com a colaboração dos paraenses Isidoro Alves, Cláudio Barradas, Alcyr Castro, Poty Fernandes e Pedro Veriano (MARTINS, 1965, p. 10) e a edição ocorreu no início do ano seguinte, em São Paulo, com o auxílio de Francisco Ramalho, João Batista de Andrade, que, juntamente com o cineasta paraense, formavam o grupo Kuatro, da Escola Politécnica. A composição da película ainda contou com a valiosa contribuição de Maurice Capovilla, que, segundo Tapajós (2002, p. 87), foi quem the ensinou "como se monta e finaliza um filme".

O projeto consistia na feitura de um curta-metragem focado nos contrastes verificados nas condições de vida e de habitação da parcela da população residente naquela "favela" - como se referiam, à época, às áreas periféricas, também chamada de "baixadas" - comparada àquelas encontradas nos bairros centrais, de urbanização recente, para daí extrair algumas "evidentes ilações sociais" (TAPAJÓS, 2002, p. 87). Por motivos de ordem técnica, a montagem acabou concentrada exclusivamente na comunidade de Vila da Barca. 
Isso ocorreu porque o "material filmado na cidade, em Belém, era péssimo", ao contrário das imagens capturadas naquela área periférica. ${ }^{10}$ Além do mais, a qualidade da gravação feita com um dos moradores impressionou tanto a equipe, que ela foi levada a se desprender do roteiro original e de suas "intenções sociológicas" iniciais para montar o documentário em torno daquele depoimento (TAPAJÓs, 2002, p. 88).

Imagem 6 - Habitações sobre palafitas, também chamadas de estivas.

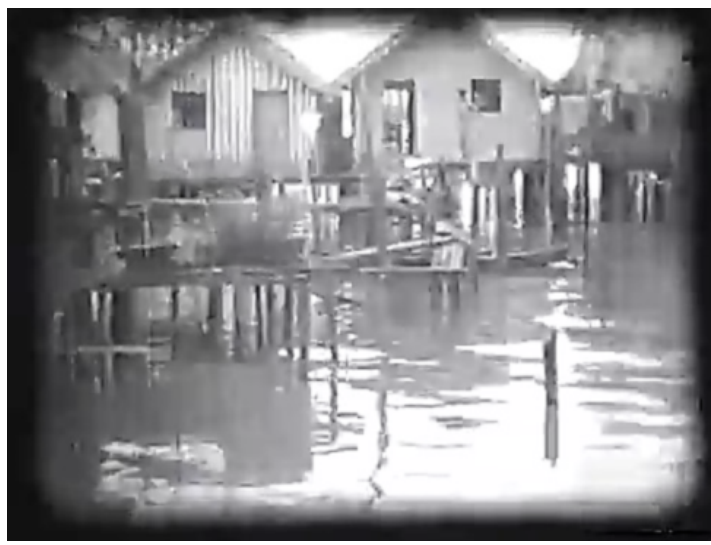

Imagem 7 - Criança na pesca de camarão sob as estivas.

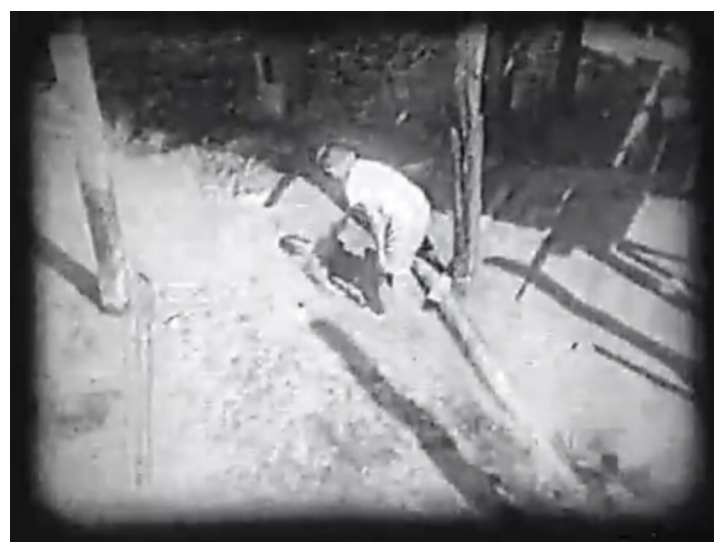

Imagem 8 - Preparo da alimentação.

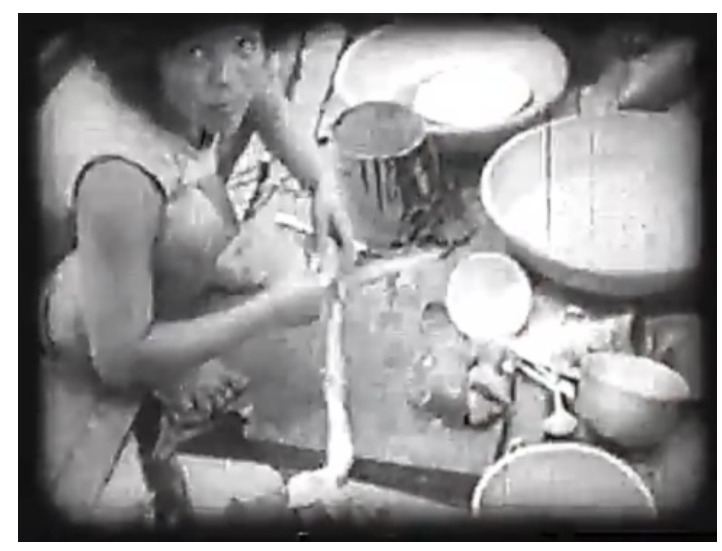

Imagem 9 - Fonte comunitária de água encanada.

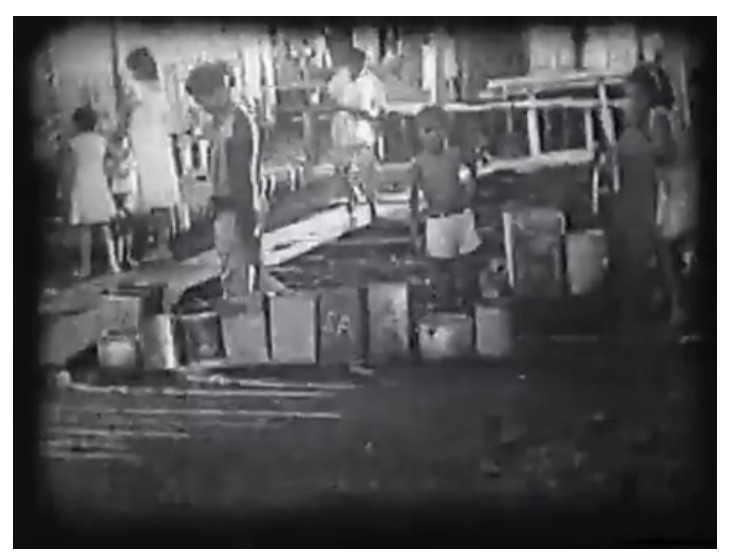

Fonte: TAPAJÓS, 1965 (documentário).

A voz over explicativa de um narrador onisciente, feita por Cláudio Mamberti, em uma estilística cara ao chamado "cinema verdade"11, apresenta ao espectador, por meio de uma linguagem "culta", aspectos considerados relevantes da vivência pobre e sofrida dos moradores da Vila da Barca. Refere-se às condições de moradia o Nota-se, na explicação de Renato Tapajós que, mesmo muito tempo depois, a dicotomia centro e periferia projeta-se quase como sinônimo de "cidade" e "não-cidade", o que, de alguma maneira, orientou a percepção dos contrastes pretendidos para documentário.

Renato Tapajós esclareceu que, nos anos 1960, ele "estava sob o impacto de três coisas: o Cinema Novo, a Nouvelle Vague e o Cinema Verdade", aproximandose mais deste, porque "o Cinema Verdade, com as propostas de utilização das técnicas de reportagem, documentário, da utilização do equipamento leve, a tal ponto que, embora a gente não tivesse o equipamento adequado para fazer Cinema Verdade, a gente partiu para fazê-lo com o que tinha na mão, o que criou coisas muito interessantes, porque são filmes típicos do subdesenvolvimento, a tentativa de utilizar os resultados formais de uma determinada tecnologia sem dispor dessa tecnologia" (apud RIDENTI, 2000, p. 100). 
12 À conclusão semelhante chegou o geógrafo Antônio Rocha Penteado (1968, p. 343), ao afirmar que a pobreza da população do bairro do Telégrafo Sem Fio "alcança sua maior expressão na Vila da Barca", onde seus moradores vivem "nas piores condições de higiene e conforto em toda Belém".

Essa atitude "intervencionista, participante do acontecimento que se filma, criadora do próprio acontecimento e que concebe o filme como um artefato que engendra suas próprias verdades", presente na montagem do "cinema verdade", é um do elementos que o diferencia do "cinema direto", preocupado em "exibir mostrar, dar a ver, tornar visível, fazer da visibilidade um fim em si mesma" (TEIXEIRA, 2006, p. 273). ("seus 800 barracos, construídos sobre as águas lamacentas do rio Amazonas, abrigam 4500 pessoas") (Imagem 6), de alimentação (seus moradores consomem peixe, farinha e camarão, "pescado pelas crianças na lama, quando a maré baixa") (Imagens 7 e 8), de trabalho (tiram seu sustendo do "trabalho nas feiras, que abastecem diariamente os bairros pobres") e de saneamento (não existia sistema de esgotamento sanitário - o rio estava ali "poluído pelos dejetos nele despejados") ou de água encanada - "apenas duas torneiras trazem água da cidade") (TAPAJÓs, 1965) (Imagem 9).

Diante dessa situação, o narrador foi levado à seguinte conclusão:

Com seus 4.500 habitantes, Vila da Barca é uma verdadeira cidade abandonada à própria sorte, sem escola, sem assistência médica, com uma primitiva e pobre economia, ameaçada pelas águas poluídas, pela tuberculose, pelo tifo, pelas mais variadas infecções. Marginalizada, Vila da Barca tende a permanecer nesse estado, até que seja encontrada a necessária solução. ${ }^{12}$
À narrativa de Mamberti, sincronizada em estúdio com as imagens correspondentes, registradas por uma "câmera de $16 \mathrm{~mm}$ movida a corda", foram intercalados trechos sonorizados e a fala de um depoente onipresente. Expressa em linguajar próprio dos moradores da localidade, a maioria oriunda do interior do estado (FURTADO e SANTANA, 1974 , p. 4 e 5), esse relato serve de fio condutor do documentário. Ele foi sintetizado e adaptado ao roteiro, com base na entrevista feitajunto a um morador, captadas por meio de um "gravador de rolo muito pesado" (TAPAJÓs, 2002, p. 87). Chama atenção a maneira resignada com que ele se exprime, ou, melhor, o tom que depoimento adquiriu ao ser ajustado, na voz de outra pessoa, para o filme, e com a qual o cineasta procura deixar mais claro seu argumento na comunicação com o público:13

Vim para cá. Pelo menos junto do rio eu fico. A patroa trabalha na castanha, quando tem safra, mas ela abortou e não pode mais esse ano. Nem pagam nada os home. Direito tinha. Então eu pergunto: pobre tem direito algum? [...] Num digo que bem não come. Nóis armoça, peixe com farinha e janta açaí. $\mathrm{E}$ 
com farinha. Todos os dias assim. Alimenta. Comer mais? Pra quê? Pobre já não tem precisão. Não sente fome mais (TAPAJÓS, 1965).

A falta de perspectiva do informante é mais um dado ressaltado na construção discursiva do documentário. Ela se manifesta impregnada de um sentido participante particular, ao denunciar aquela vivência espoliada em uma urbe que se moderniza, fruto, entre outras coisas, da exploração de força de trabalho, das desigualdades sociais e da omissão estatal quanto à garantia de direitos mínimos. Na prática, a Vila da Barca é tratada aí como mais um daqueles espaços "sem cidadãos" a que se refere Milton Santos (2007, p. 59), caracterizados por extensas áreas presentes em várias capitais brasileiras, totalmente "desprovidas de serviços essenciais à vida social e à vida individual". Ao comentar, assim, aspectos reveladores do modo de vida dessa população pobre na década de 1960, a película adquire significação histórica e sentido crítico quando a realidade ali apresentada é vista em contraste com o processo de mudanças pelo qual passava a cidade.

Ao mesmo tempo em que as ruas centrais recebiam novo asfaltamento, bangalôs eram erguidos sobre os escombros de barracos e de antigos casarões de estilo colonial, novas estradas e ruas eram construídas e pavimentadas, fazendo aumentar o fluxo de pessoas e de veículos, Belém convivia com um numeroso contingente populacional residente em áreas pouco ou quase nada assistidas por esses melhoramentos. Esse fenômeno tenderia a se intensificar, nos anos 1970, em função dos processos migratórios acionados pelos projetos de colonização implantados na região, desde o final dos anos 1960 (IBGE, 2002, p. 13-16).

A crescente migração, fundada na lógica do deslocamento de "homens sem terras" do Nordeste e de outras regiões do país para a "terras sem homens" da Amazônia (PETIT, 2003, p. 87), aliada às modificações ocorridas no plano urbano, viriam tornar mais agudas as já precárias condições de vida. Não à toa, a personagem que 
fala ao público no documentário, demonstra preocupação com a possibilidade de se ver despejada do lugar, porque tomara conhecimento de que a Marinha tencionava derrubar todos os barracos de Vila da Barca "pra encompridar o porto" - "pode?", perguntava ele, "eles têm direito di dirrubar?". E completava conformado: "me dissero qui é assim nos regulamento das lei". $\mathrm{Na}$ sua última participação, o depoente sintetiza aquilo que 0 cineasta e seus colaboradores pretendiam comunicar: "pobre já não tem direito nenhum!" (TAPAJÓs, 1965).

A possibilidade de ficar sem um teto para morar era algo real para muitos que residiam nas áreas urbanizadas ou em

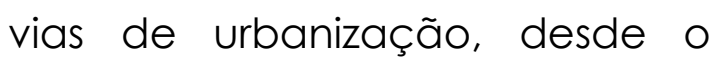
início da década. Como muitos outros a partir de então, esse foi o caso de Dona Rosinha, moradora da Rua Generalíssimo Deodoro, no Umarizal, ao se ver obrigada a deixar a casa em que habitava há mais de trinta anos. O bairro se modernizava e seu principal corredor viário ganhava melhoramentos, o que contribuiu para o aumento do custo de vida e da especulação imobiliária em seu entorno. Sem ter condições de se manter ali, ela não viu outra opção senão a de ir morar em uma área de ocupação espontânea, no bairro da Marambaia, em condições nada favoráveis: "a casa, uma barraquinha melhorada, não tem água nem luz, nem quintal cercado. É rés do chão". O colunista de jornal, vendo aquilo, emendou ironicamente: "é o preço do progresso" (LOPES, 1960, p. 8).

Os contrastes de uma cidade em transe, para além dos discursos jornalísticos e oficiais, eram captados de diferentes formas, por outras vias. No curta-metragem mudo Brinquedo Perdido, de 1962, Pedro Veriano conta um episódio curioso ocorrido na vida de um pequeno vendedor ambulante (Assis Miranda). A trama tem início quando ele, morador da periferia, sai para trabalhar, levando em uma das mãos a bandeja de bolo apoiada ao ombro e, na outra, um brinquedo artesanal, composto por haste de ferro arqueada em uma das extremidades para equilibrar e fazer girar uma roda de borracha. 
No caminho, a personagem vivida pela personagem, que se encontra um caminhãozinho de viu abruptamente alijada de seu plástico, fabricação industrial, objeto de prazer. perdido junto à lixeira na calçada.

Daí em diante, o pequeno vendedor percorre, brincando com o carrinho, algumas vias e espaços públicos das áreas comerciais mais antigas, como o Porto do Sal, a Doca do Vero-Peso e a Feira da Praia, e de remodelação recente, a exemplo da Av. Presidente Getúlio Vargas e da Praça da República. Para sua surpresa, de volta a esse passeio público, depois de tantas idas e vindas, ele se depara com a criança dona daquele brinquedo, que havia animado seu dia de labuta. A mãe do garoto, vendo o objeto em poder de um estranho, tomou-lhe à força e o devolveu ao filho. Ante a violência sofrida, contra a qual não esboçou reação, o ambulante retoma o caminha de volta para sua casa, cabisbaixo e triste, sem o antigo e o novo passatempo. Dessa forma, Pedro Veriano (1999, p. 47) procurou imprimir, em dez minutos de imagem em movimento, a sua "pretensão dramática"14, centrada na desilusão pessoal de $16 \mathrm{~mm}$, de forma amadora e

Visto em uma perspectiva histórica, verifica-se que o trágico não se inscreve aí ao acaso ou de maneira neutra. Ele não se manifesta como a tradução de um sentimento individual imutável e isolado, especialmente quando, em suas diversas conotações (sofrimento, morte, incerteza, angústia, injustiça social), ganha ressonância na obra de arte (WILLIAMS, 2002, p. 57). Ele se relaciona ao movimento geral da história, um contexto e realidade social específicos em que se vivencia uma série de transformações decisivas, diante das quais o cineasta se vê na necessidade de intervir, de agir, por meio de sua arte. Afinal, o drama pessoal da personagem não teria sido expresso dessa forma se experiências sociais "trágicas" como essa não fossem sentidas como tais, tanto para o produtor como para o público, a ponto de lhes tocar de algum modo, naquele momento.

O curta foi gravado em suporte
14 Essa intenção orientou outras "brincadeiras" em $16 \mathrm{~mm}$ de Pedro Veriano, como O desastre, $O$ deus de ouro e Vendedor de pirulitos, exibidas no cine clube Bandeirantes, improvisado na garagem da casa onde morava. de $16 \mathrm{~mm}$, de forma amadora e 
quase artesanal, como a maioria dos filmes de Pedro Veriano nesse período. A montagem, concebida sem o uso de negativos, "na base da emenda na cópia, prevendo-se o mínimo na hora de filmar" (VERIANO, 1999, p. 56), buscou valorizar o que de imediato foi registrado pela câmera. As limitações técnicas, provavelmente, o impediram de proceder a edição sonora correspondente - essa é uma hipótese diante da falta de evidências de que a ausência da fala, texto ou qualquer sonorização tenha sido uma opção estética. Em todo caso, esses obstáculos, ao mesmo tempo em que incidiram sobre a apresentação formal do curta-metragem e demonstraram as dificuldades de se fazer cinema na capital paraense, não foram suficientes para que, em termos discursivos, aspectos importantes da cidade e sua gente deixassem de ser captados pela lente guiada segundo 0 filtro do produtor. Dessa maneira, foram explicitadas algumas diferenças e contradições relativas à expediência de viver em uma urbe que se pretendia moderna e em desenvolvimento.
Logo na abertura, vê-se estampada a imagem do Edifício Manoel Pinto da Silva, símbolo da tendente verticalização de Belém, cuja construção do conjunto de seus três blocos foi iniciada em 1948 e concluída em 1960. Em seguida, as primeiras cenas registram, em tomadas elevadas, possivelmente realizadas do alto desse prédio, imagens de áreas centrais em contraste com a periferia, carente de edificações modernas, de paisagem mais plana e vegetação acentuada.

As discrepâncias sociais e econômicas subjacentes ao drama narrado imageticamente por Pedro Veriano manifestamse, também, na aparência da personagem central. Maltrapilha, de short e camisa rasgados, ela caminha descalça por várias ruas e espaços público de Belém, com um figurino bem diferente da roupa engomada, o belo par de sapatos e os cabelos cortados e cuidadosamente penteados do garoto de classe média, que, ainda, ostentava um lindo relógio de pulso quando passeava com a mãe, na Praça da República (Imagens 10 e 11). Além do mais, enquanto este 
brincava, aquela outra criança trabalhava na venda de doce na rua para contribuir com o sustento doméstico, algo aparentemente pouco questionado ou questionável no presente vivido. Evidencia-se, assim, uma maneira característica de percepção do trabalho infantil no período, como algo necessário e frequente entre famílias de comunidades pobres, como nesse caso e na localidade de Vila da Barca. Para completar, a mãe demonstra certa repulsa em relação ao vendedor, ao impedir que seu filho se aproximasse dele, ao mesmo tempo em que the tomava o brinquedo violentamente e, gesticulando de maneira ostensiva, exigia que ele fosse embora dali (Imagens $12 \mathrm{e}$ 13).
Imagem 10 - Vendedor ambulante.

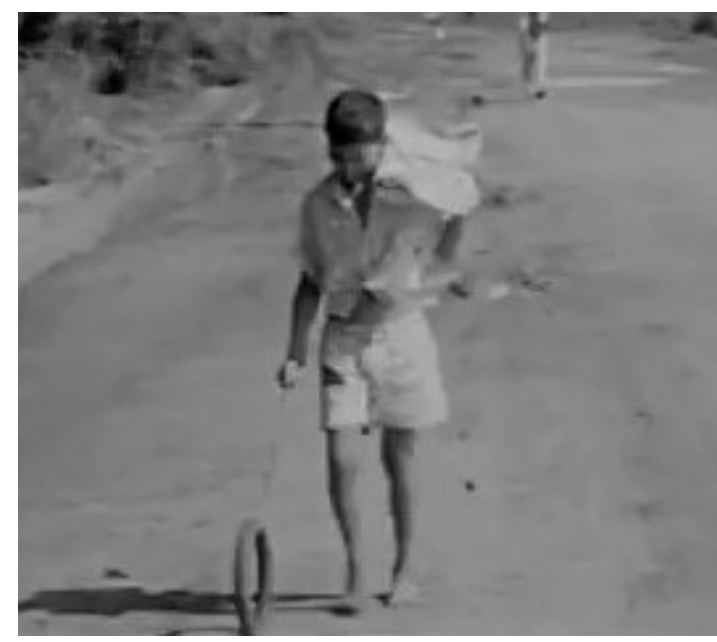

Imagem 11 -Criança brincando na praça.

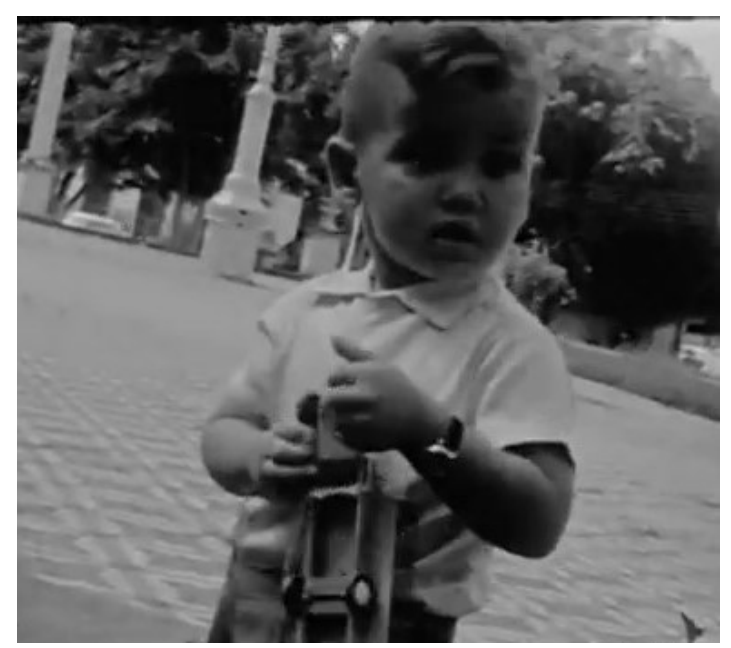

Imagem 12 -Mãe, afastando o filho do vendedor.

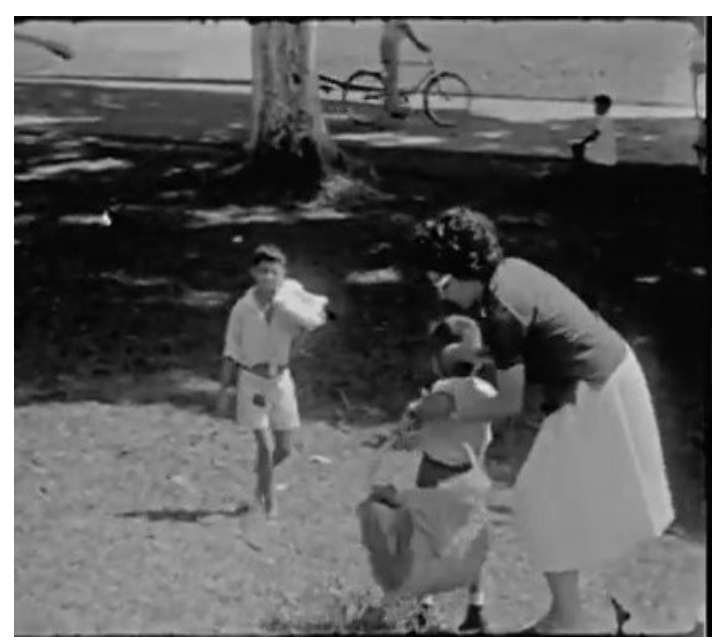


Imagem 13 -Mãe, retirando o brinquedo das mãos do vendedor.

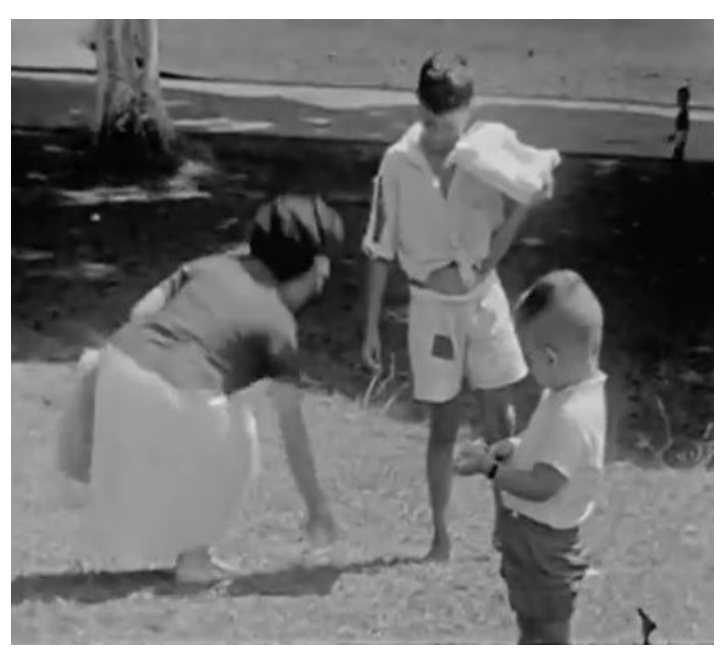

Fonte: VERIANO, 1962 (curta-metragem)

Os gestos e atitudes enquadrados nas imagens extraídas das sequências do curta explicitam, na ficção, a (in) sensibilidade, não só daquela mãe, em específico, diante da personagem, como, também, comentam uma formaidentificável de comportamento social de uma parcela da população em semelhante posição e condição socioeconômica. Vistos numa perspectiva indutiva, eles levam, de algum modo, o espectador a refletir sobre os temas abordados, ao acrescentarem nuance sociais a partir do drama pessoal de um jovem e maltrapilho vendedor de rua.

$\mathrm{Na}$ contramão do que se percebe em Brinquedo Perdido e em Vila da Barca, Líbero Luxardo, cineasta paulista aqui radicado desde o final da década de 1930, imprimiu uma ótica oficialista ao documentário Belém 350 anos. Ele foca com otimismo e positividade as mudanças urbanísticas e arquitetônicas da capital paraense e as implicações sociais e culturais decorrentes desse processo.

Produzido, em 1966, em comemoração à passagem do aniversário de inauguração de Belém, os planos dessa película foram concebidos de maneira a flagrar uma cidade "bela e progressista", recheada de "magníficos clubes" frequentados pelos estratos médios e altos da sociedade e equipada com uma universidadeem fase de ampliação e novos estabelecimentos comerciais, industriais e bancários, devotados ao "soerguimento da região" (LUXARDO, 1966). Esse seria o lugar em que os melhoramentos davam sinais incontestes de que o desenvolvimento pedia passagem, atestando, assim, a condição pretendida de "Metrópole da Amazônia" brasileira.

A voz over de Cid Moreira exalta um contexto urbano marcado pela impressionante "harmonia" 
de duas épocas distintas: a "tradicional", simbolizada pela arquitetura colonial (igrejas e casarões) e por aquela introduzida no período áureo de extração e comercialização da borracha (mercados e chalés de ferro, Teatro da Paz, etc.), e a "moderna", identificada por seus "novos e suntuosos arranha-céus" (LUXARDO, 1966) (Imagens 14 e 15). ${ }^{15}$

Imagem 14 - Centro comercial antigo e, ao fundo, conjunto de prédio residenciais.

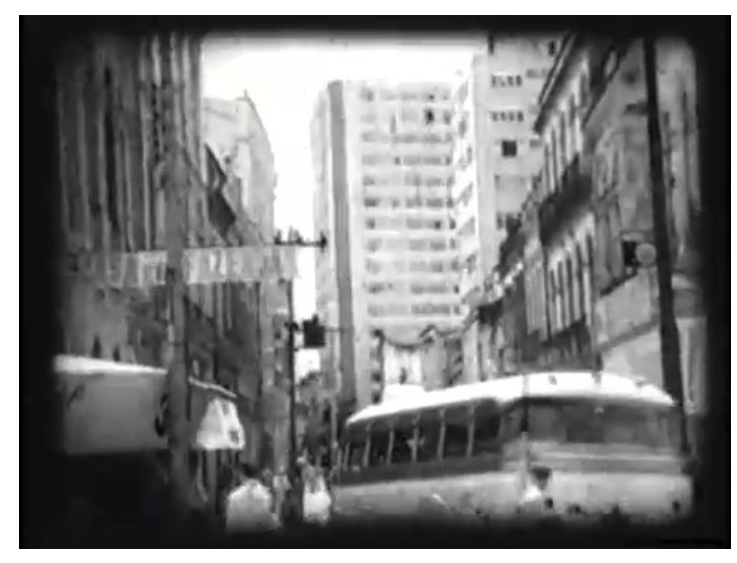

Imagem 15 - Monumento à República e Teatro da Paz e, ao fundo, conjunto de

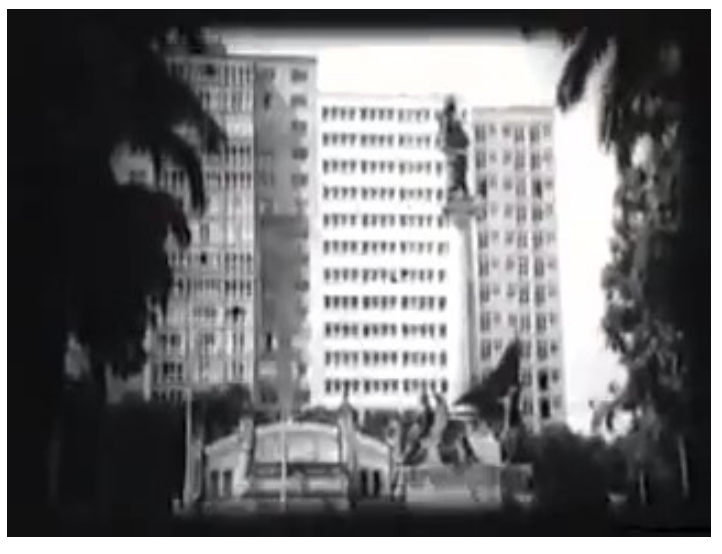

Fonte: LUXARDO, 1966 (documentário)
Não há como deixar de notar que o caráter laudatório dessa produção entra em rota de colisão com o longa-metragem Um dia qualquer (LUXARDO, 1965), realizado pelo mesmo cineasta. Se, no documentário, são pontuados, positivamente, elementos que demonstram, aos olhos oficiais e do produtor, o desenvolvimento da capital paraense, em seusaspectos mais visíveis e relacionados a determinados estratos sociais, na ficção, lançada no ano anterior, o entendimento era outro.

A narrativa fílmica é enredada no drama pessoal da personagem Carlos (Hélio Castro), um típico homem de classe média, abalado pela morte repentina e violenta da bela e grávida esposa, Maria de Belém (Lenira Guimarães), durante uma batida policial realizada para debelar a confusão formada pelo encontro de bois-bumbás rivais na Praça da República. Após as exéquias, o protagonista vagueia sem direção ou destino, qual um fâneur fantasmagórico, absorvido pela tristeza do agora e pelas lembranças felizes de outrora ao lado da mulher amada (OLIVEIRA, 2012, p. 25-53). Sua presença física nos lugares por onde passa ou
5 Antônio Rocha Penteado usou, entre outras fontes, o recurso fotográfico como forma de comprovar 0 processo de modernização da Belém, comparando imagens do final dos anos 1940 à meados da década de 1960. Algumas delas, inclusive, lembram enquadramentos registrados nas sequências do filme de Líbero Luxardo. Diferentemente ao documentário, no entanto, o geógrafo ressaltou a persistência ou $O$ agravamento de problemas socioeconômicos relacionados, por exemplo, ao abastecimento de alimentos, condição dos serviços públicos e de circulação interna. 
naqueles evocados, em fleches, pela memória, descortinam 0 palco e a personagem central dessa história.

Ao apresentar um espectro humano em uma cidade que se tornara estranha a ele, o filme emoldura, de maneira peculiar, a figura de uma Belém transformada, não apenas em suas características físicas, como também, e principalmente, emseus valores e costumes. Cada plano, cada sequência, afora as cenas alegres do casal, deixam escapar a interpretação que o cineasta faz das mudanças socioculturais sentidas naquele momento, que indica caminho possivel de compreensão histórica desse documento cinematográfico (FERRO, 1999, p. 88).

É O que sinalizam as cenas do xingamento do taxista a um motorista de caminhão que cruza a frente de seu carro, da prostituição próxima as áreas centrais, de rapazes embriagados, urinando na rua, do casal discutindo na calçada, em razão da traição do marido (Imagem 16) e da sequência em que uma moça incorpora uma entidade no terreiro de "macumba" (Imagem 17). Tudo isso se passa em frente dos olhos de Carlos.
Imagem 16 - Discussão de casal em via pública.

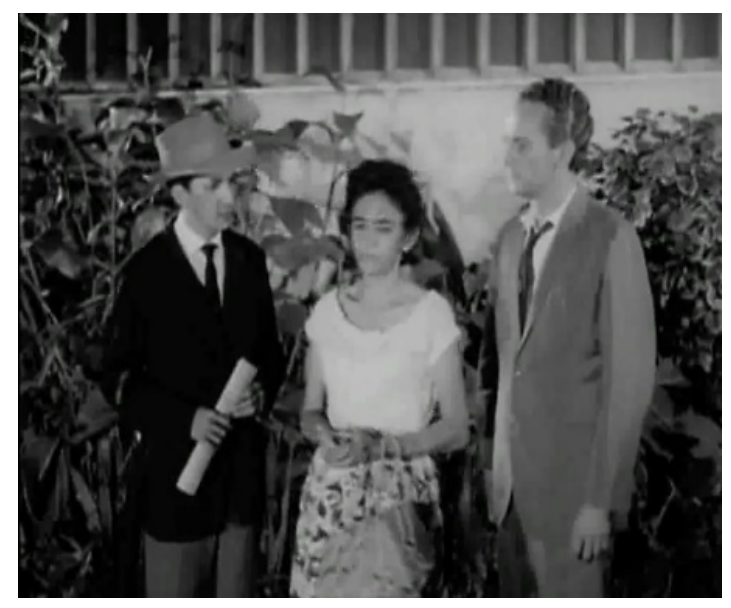

Imagem 17 - Incorporação de entidade no terreiro.

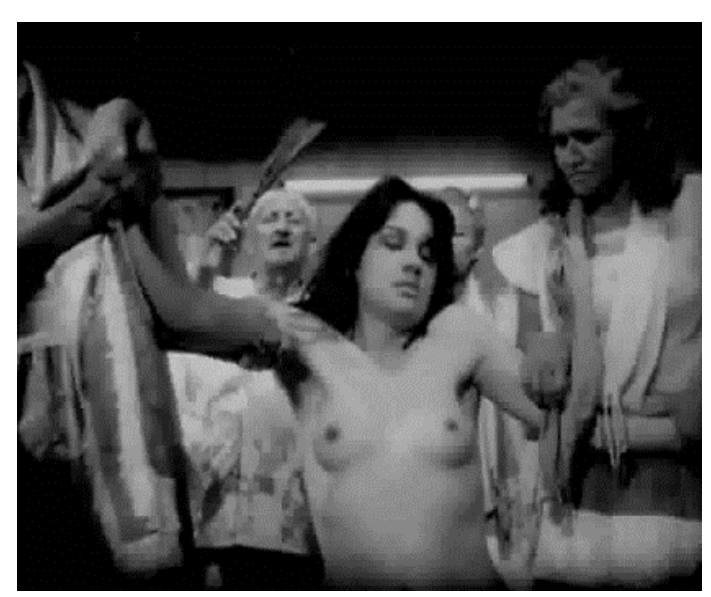

Imagem 18 - Strip-tease à margem do igarapé.

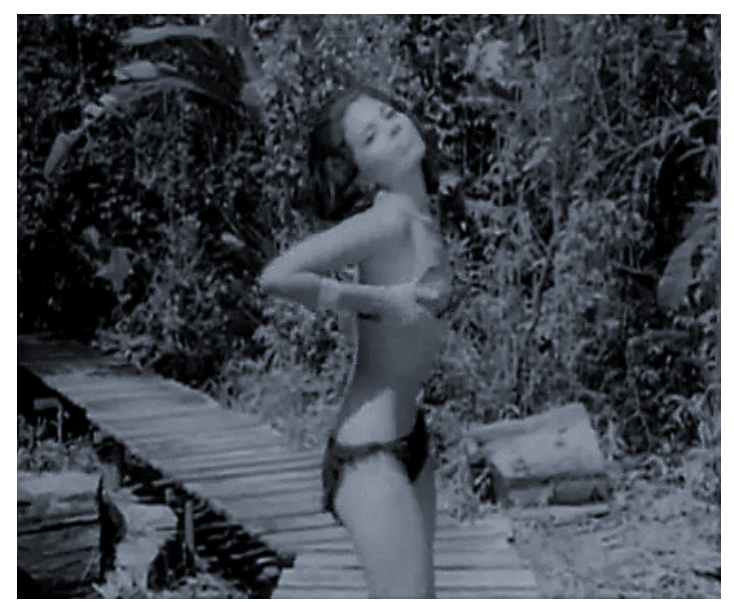


Imagem 19 - Furto de objetos sacros escondidos no caixão.

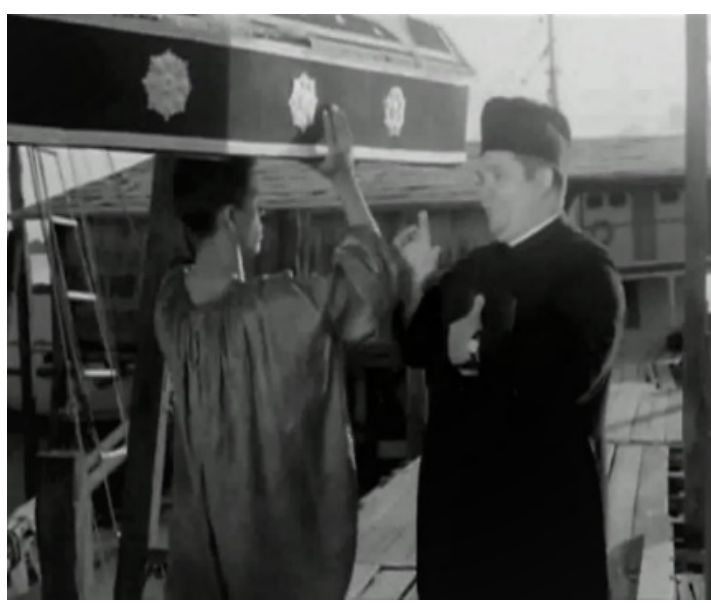

Fonte: LUXARDO, 1965.

Outros planos, alheios à Grão-Pará, agora intensamente percepção da personagem, mergulhada nos dramas da vida completam esse quadro moderna. O caos no trânsito degradante: $\quad$ strip-tease - ao fim do dia, Carlos morre praticado, sob efeito de bebida atropelado -, a violência urbana, alcóolica, por uma jovem para seduzir o namorado, chamando-o para banhar-se com ela em um igarapé (Imagem 18), o estupro sofrido por uma colegial, que havia "gazeteado aula" para ir se divertir no bar e o furto de objetos sacros da Igreja do Carmo, por um ribeirinho, que, a caminho de sua embarcação, ainda recebe a benção do vigário (Imagem 19).

O retrato físico e valorativo projetado da capital paraense $e$ de seus habitantes deixa vazar a perspectiva conservadora com a qual Líbero Luxardo percebeu as mudanças do período. O longa descortina, assim, aspectos "invisíveis" do viver na capital paraense, que, à época, tocavam fundo a sensibilidade do cineasta, a ponte de denunciá-los.

A morte da ingênua e bela Maria de Belém pode ser entendida como uma transposição performática para o cinema da "morte" simbólica da antiga Santa Maria de Belém do a prostituição, a desobediência juvenil, a emancipação feminina e a profanação de um templo religioso, tudo isso são tomados como sintomas do tempo, que, vividos ou vivenciados por aquela personagem - uma espécie de alter ego de Líbero Luxardo -, ganharam coloração acentuada em "Um dia qualquer".

Dessa forma, ele lança um olhar saudosista com o qual procurou demonstrar "o seu grande amor" pela cidade que ele adotou como sua. Luxardo dirá, anos depois, 
que as imagens estampadas nessa sua produção procuraram revelar "um fundo mental pessoal onde realidade e conceito são ligados, observando princípios convencionais" das condições de realização cinematográfica do período (LUXARDO, 1977, p. 42). Consciente ou não disso doze anos antes, a forma como foi concebido, filmado e montado esse longa metragem, expressa a maneira com que ele pretendeu dar significação à mensagem a ser comunicada, valendo-se, para tanto, dos recursos cênicos e das técnicas colocadas a sua disposição.

Mais que isso, o filme expressa a tensão sentida e vivida ativamente pelo seu idealizador, entre a experiência histórica que, para ele, estava sob ameaça, ao mesmo tempo em que projeta expectativas futuras nada animadoras. Dessa tensão, subjaz uma preocupação com a necessidade de se ajustar o passo com a modernidade, ou seja, de usufruir dos equipamentos e melhoramentos da vida moderna de numa urbe em transformada, sem se esquivar da preservação de determinados princípios morais e práticas costumeiras, que ele julgava essenciais ao viver citadino.

\section{Considerações Finais}

Nas produções artísticas referenciadas e discutidas até aqui, é possível observar que havia distintas maneiras de conceber o que significava ser e viver em Belém, em meados dos anos 1960. O exame de algumas realizações cinematográficas e experimentações no campo das artes plásticas ajuda a refletir sobre as articulações entre questões socioculturais e estéticas que, direta ou indiretamente, atribuíram força expressiva às obras.

Renato Tapajós, Pedro Veriano e Líbero Luxardo lançaram olhares cruzados sobre a cidade, a partir de ângulos distintos, havendo em comum entre eles o fato de terem captado e manifestado, cada um a seu modo, sentimentos difusos em relação às mudanças urbanísticas e socioculturais aí verificadas.

Se para Luxardo elas eram sinônimo de progresso material e caos moral, para Tapajós e Veriano elas reforçaram os distanciamentos 
$e$ as desigualdades sociais e econômicas. O realismo com que esses cineastas abordaram - cotidiano em Vila da Barca e Brinquedo Perdido, ressalta contradições do viver em uma urbe em processo de transformação, que, nas películas de Líbero Luxardo, foram silenciadas ou vistas em suas implicações morais.

Por outras vias, as obras apresentadas na mostra do Grupo destoaram dos olhares mais conservadores e de certas convenções locais. Elas foram exibidas no período no qual aquele tipo de arte experimental tinha pouca ressonância em Belém e quando os parâmetros de legitimidade artística eram outros. Talvez, por isso, os quadros que compuseram a exposição tenham chamado atenção muito mais pela ousadia, ao abordar temas urbanos e propor técnicas e composições formais em sintonia com algumas referências das vanguardas nacionais, do que pelo reconhecimento do valor estético, em um tempo no qual o ideal de arte, aqui, ainda transitava entre o figurativismo acadêmico e as tendências abstracionistas.

Essas experiências na pintura, trazidas pelo Grupo, e no cinema, relativamente às contribuições de Renato Tapajós, Pedro Veriano e Líbero Luxardo, adquirem significação histórica, entre outras coisas, porque nelas se observa atitudes e percepções dissonantes do mesmo processo, umas mais inconformistas e com propostas de renovação, em contraposição aos padrões já enraizado na capital paraense, e outras com um tom mais conservador, saudosista e moralizante.

Tratam-se de concepções artísticas que, em linguagens distintas, evidenciam que, independentemente da intenção de seus criadores, a cidade foi apreendida como tema, motivação ou personagem, em suas feições e contradições socioculturais e físicas. Entendidas como "experiências sociais em solução", essas manifestações da consciência prática de seus realizadores (WILLIAMS, 1979, $\mathrm{p}$. 136) propuseram alternativas de interpretação do presente vivido em um lugar, que, mesmo à margem das formações culturais dominantes, indicavam caminhos próprios em direção à estruturação de novas figuras semânticas nas artes em Belém. 


\section{Referências}

CHAVES, Túlio Augusto Pinho de Vasconcelos. Isto não é para nós? Um estudo sobre a verticalização e modernidade em Belém entre as décadas de 1940 e 1950. 2011. Dissertação (Mestrado em História) IFCH/UFPA, Belém.

CHAVES, Túlio Augusto Pinho de Vasconcelos. Patrimônio e Progresso: Belém 1960-1970. In: X Seminário de História da Cidade e do Urbanismo, Recife, 2008.

COSTA, Gil Vieira. Estela Campos e os momentos iniciais do abstracionismo no Pará (1957-1959): hipótese sobre invisibilidades na história da arte. Boletim do Museus Paraense Emílio Goeldi. Ciências Humanas, Belém, v. 13, n. 3, p. 699-717, ser./dez. 2018.

COSTA, Gil Vieira. Arte em Belém, do abstracionismo à visualidade amazônica (1957-1985): transições movediças e tensões globais. 2019. Tese (Doutorado em História) - Universidade Federal do Pará.

COUTO, Maria deuma i Fátima Morethy. Por uma vanguarda nacional: a crítica brasileira em busca de dentidade artística (1940-1960). Campinas: Editora da Unicamp, 2004.

FERRO, Marc. Cinema e história. Rio de Janeiro: Paz e Terra, 1992.

FURTADO, Lourdes Gonçalves e SANTANA, Maria da Conceição. "Vila da Barca", Belém: notas sobre grilagem. Boletim do Museu Paraense Emílio Goeldi. Antropologia, Belém, n. 52, jan. 1974.

GODINHO, Sebastião. Galeria "Ângelus": 20 anos de arte no Pará (I). Diário do Pará, 26 e 27 out 1986a, p. 7.

GODINHO, Sebastião. Galeria "Ângelus": 20 anos de arte no Pará (II). Diário do Pará, 9 e 10 nov. 1986b, p. 3. 
GONÇALVES, Simone Bandeira. Entrevista concedida ao autor. Belém 5 mar. 2013.

GULLAR, Ferreira. Vanguarda e subdesenvolvimento. Rio de Janeiro: Civilização Brasileira, 1969.

IBGE. Tendências demográficas: uma análise dos resultados do universo do censo demográfico 2000 - Pará. Rio de Janeiro: IBGE, 2002.

KOSELLECK, Reinhart. Futuro passado: contribuição à semântica dos tempos históricos. Rio de Janeiro: Contraponto; Ed. PUC, 2006.

LAMBERT, Jacques. Os dois Brasis. São Paulo: Companhia Editora Nacional, 1969.

LOPES, Carlos Gomes. Progresso da cidade custa choro de pobres. A Província do Pará. Belém, 12 jun. 1960.

LUXARDO, Líbero. DVD Um dia qualquer. 35mm, 80 min, 1965 (longametragem). Acervo da Biblioteca Arthur Vianna, Centur, Seção de Audiovisual, Belém.

LUXARDO, Líbero. DVD Belém 350 anos. $16 \mathrm{~mm}, 10 \mathrm{~min}, 1966$. (documentário). Acervo da Biblioteca Arthur Vianna, Centur, Seção de Audiovisual, Belém.

LUXARDO, Líbero. Os três níveis da comunicação cinematográfica. Espaço, ano I, n. 3, Belém, dez. 1977.

MARAJÓ, Flávio. Jovem arte ou a revolução do Grupo. A Província do Pará, Belém, 4 dez. 1966, p. 1.

MARTINS, Edwaldo. "Vila da Barca". A Província do Pará, Belém, 3 jan. 1965, 2. cad., p. 10. 
MERCÊS, João Cesar. Entrevista concedida ao autor. Belém, 12 jan. 2013.

MORAES, Cleodir da Conceição. O norte da canção: música engajada em Belém nos anos 1960 e 1970. 2014. Tese (Doutorado em História) UFU, Uberlândia.

NAVES, Santuza Cambraia. Os novos experimentos culturais nos anos 1940/1950: propostas de democratização da arte no Brasil. In: FERREIRA, Jorge e DELGADO, Lucília de Almeida Neves (org.). O Brasil Republicano: o tempo da experiência democrática-da democratização de 1945 ao golpe civil-militar de 1964. Rio de Janeiro: Civilização Brasileira, 2003.

OLIVEIRA, Francisco de. A economia brasileira: crítica à razão dualista. Estudos Cebrap, v. 2, São Paulo, p. 3-82, out. 1972.

OLIVEIRA, Relivaldo Pinho de. Amazônia, cidade e cinema em Um dia qualquer e Ver-o-peso: ensaios. Belém: IAP, 2012.

PENTEADO, Antônio Rocha. Belém do Pará: estudo de geografia urbana. V. 1 e 2. Belém: Universidade Federal do Pará, 1968.

PETIT, Pere. Chão de promessas: elites políticas e transformações econômicas no Estado do Pará pós-1964. Belém: Paka-Tatu, 2003.

REIS, Paulo Roberto de Oliveira. Exposições de arte: vanguarda e política entre os anos 1965 e 1970. 2005. Tese (Doutorado em História) Universidade Federal do Paraná, Curitiba.

RIDENTI, Marcelo. Em busca do povo brasileiro: artistas da revolução, do CPC à era da TV. Rio de Janeiro-São Paulo: Record, 2000.

SANTOS, Milton. O espaço do cidadão. 7.ed. São Paulo: Editora da Universidade de São Paulo, 2007. 
SOBRAL, Acácio de Jesus Souza. Momentos iniciais do abstracionismo no Pará. Belem: IAP, 2002.

TAPAJÓS, Renato. DVD Vila da Barca. Belém, 16mm, $10 \mathrm{~min}, 1965$ (documentário). Acervo da Biblioteca Arthur Vianna, Centur, Seção de Audiovisual.

TAPAJÓS, Renato. Ofício de documentarista ou olho da câmera não mente. Comunicação e Educação, São Paulo, n. 24, maio/ago. 2002.

TEIXEIRA, Francisco Elinaldo. Documentário moderno. In: MASCARELLO, Fernando. História do cinema mundial. Campinas: Papirus, 2006,

VERIANO, Pedro. Brinquedo Perdido. 16mm, 8min, 1962 (curta-metragem), Belém. Disponível em <www.cinematecaparaense.wordpres.com>. Acesso em 6 mar 2020.

VERIANO, Pedro. A crítica de cinema em Belém. Belém: Secdt, 1983.

VERIANO, Pedro. Cinema no tucupi. Belém: Secult, 1999.

WILLIAMS, Raymond. Marxismo e literatura. Rio de Janeiro: Zahar Editores, 1979.

WILLIAMS, Raymond. Tragédia moderna. São Paulo: Cosac e Naify, 2002. 